\title{
Karstification and Tectonic Effects on the Drainage Trend in the Southwestern Part of Iraq
}

\author{
Varoujan K. Sissakian', Nadhir Al-Ansari² \\ ${ }^{1}$ University of Kurdistan, Erbil, Iraq \\ ${ }^{2}$ Lulea University of Technology, Lulea, Sweden \\ Email:varoujan49@yahoo.com,nadhir.alansari@ltu.se
}

How to cite this paper: Sissakian, V.K. and Al-Ansari, N. (2017) Karstification and Tectonic Effects on the Drainage Trend in the Southwestern Part of Iraq. Engineering, 9, 703-722.

https://doi.org/10.4236/eng.2017.98043

Received: July 14, 2017

Accepted: August 27, 2017

Published: August 30, 2017

Copyright (c) 2017 by authors and Scientific Research Publishing Inc. This work is licensed under the Creative Commons Attribution International License (CC BY 4.0).

http://creativecommons.org/licenses/by/4.0/

\section{(c) (i) Open Access}

\begin{abstract}
The extreme southwestern part of Iraq forms a flat terrain, but densely dissected by valleys that flow in different directions with different types. The exposed rocks are horizontally lying, mainly of carbonates of Ratga Formation; Eocene in age; however, eastwards Cretaceous rocks are exposed of different formations; also mainly carbonates with some intercalations of fine clastics and marls. The concerned area is intensely karstified; exhibiting different karst forms and sizes. It is also intensely parted by lineaments of different orientations, which have controlled the drainage style and flow direction. Tectonically, the concerned area lies within the Outer Platform (Unstable Shelf) of the Arabian Plate. Structurally, apart from two main normal faults of $\mathrm{E}-\mathrm{W}$ trend and intense jointing and lineaments; no other features exist in the area. The intense karstification, presence of lineaments and neotectonic activities has controlled the trends of the valleys forming very complex water shades and basins that locally interfere with each other. These abnormal drainage style and different flow directions of the valleys are studied and correlated with the regional tectonic frame of the region. Moreover, we have used subsurface data; such as groundwater flow directions and geophysical data to indicate the reasons for existing of abnormal drainage style and flow directions of surface water.
\end{abstract}

\section{Keywords}

Karstification, Lineaments, Drainage, Neotectonic, Iraq

\section{Introduction}

The southwestern part of the Iraqi Western Desert along the International 
boundaries with the Jordan and Saudi Arabia represents a flat terrain with local isolated hills. This area is rich in its natural resources. It is covered by carbonate and fine clastic rocks that are intensely dissected by valleys of different drainage patterns, besides different karst forms that are also intensely developed in the studied area (Figure 1). The area is also characterized by abnormal drainage system that has not been studied before.

Different studies were carried out in the studied area; they deal with different geological aspects that are directly and/or indirectly related with the current study. The most significant studies as related to the current study are briefly mentioned hereinafter.

[1] conducted regional geological mapping for the western half part of the studied area, whereas [2] covered the eastern half part of the area. [3] conducted detailed geological mapping for the eastern part of the studied area, it was forwarded to mineral exploration. All those works reported about the stratigraphy, structure and tectonics, geomorphology of the area.

[4] [5] [6] [7] reported about the geomorphology, structure and tectonics, stratigraphy, mineral occurrences and hydrogeology of the Iraqi Western Desert. All the mentioned works didn't deal with the scope of the current study.

Sissakian et al. [8]; however, reported about different geological aspects of wadi Hauran, the largest valley in the studied area; as well in Iraq. They reported about the lineaments and their role on the trend of wadi Hauran.

The main aim of this study is to indicate the reasons for the development of complex drainage style with different drainage patterns and different trends of valleys.

\section{Materials and Methods}

In order to achieve the main aim of this study the following materials were used:

- Geological maps of different scales of the studied area.

- Hydrogeological maps of different scales of the studied area.

- Geophysical maps of different aspects of the studied area.

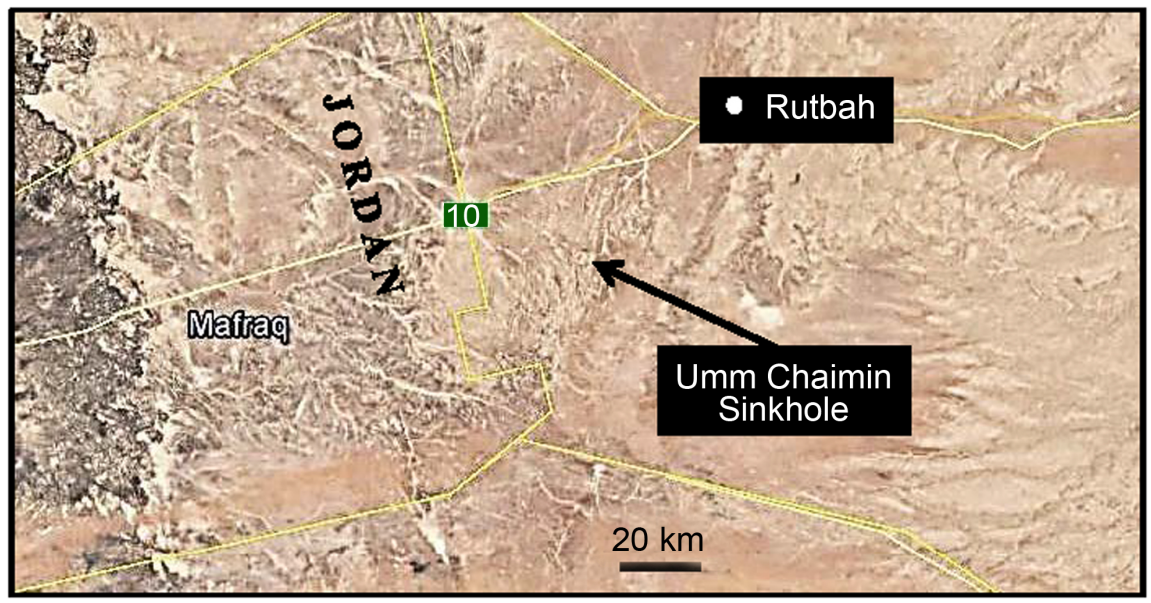

Figure 1. Google Earth image showing the studied area and near surroundings. 
- Topographic maps of different scales of the studied area.

- Google Earth, FLASH Map and DEM images.

Using the available geological and topographical maps of different scales with the help of FLASH Map, Google Earth, and DEM images, the drainage patterns, valley trends, karst forms and lineaments were studied and analyzed. Subsurface data, such as groundwater trends and geophysical data are used to check the coincidence of the surface and subsurface water trends. Lineaments' trends are checked whether they coincide with geophysical anomalies and/or structural and tectonic features.

\section{The Study Area and Its Geological Setting}

The studied area is located in the extreme southwestern part of the Iraqi territory within the Iraqi Western Desert along the International borders with Jordan and Saudi Arabia and extends slightly out of the Iraqi territory inside Jordan and Saudi Arabia (Figure 1).

The main geological aspects of the studied area are briefly reviewed hereinafter.

\subsection{Geomorphology}

The most common and widely developed geomorphological units in the studied area are:

\subsubsection{Fluvial Units}

Among the fluvial units the following are well developed in the studied area:

Flood Plain (Holocene): Flood plain is well preserved along the course of main valleys (Figure 2 ) and their main tributaries; locally two stages can be seen. The composition of the sediments is mainly coarse sand, silt and very rare clay; very rarely some pebbles are present too. The top layer; however, is usually covered by silty clayey soil, which interfingers with the hill wash sediments derived

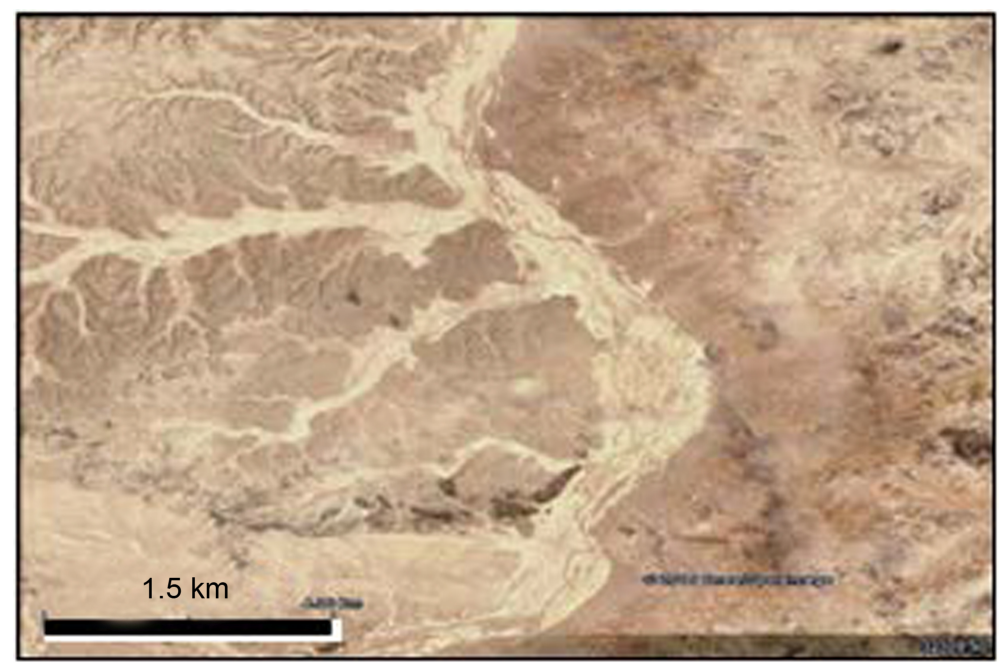

Figure 2. Google Earth image of flood plain along wadi Hauran. 
from adjacent cliffs. The thickness varies from $(1-2) \mathrm{m}$, but may reach $3 \mathrm{~m}$.

Valley Fill (Holocene): Along the course of wadi Hauran and other main valleys and even their main tributaries, valley fill sediments are well developed (Figure 3). The main constituents are gravels and coarse sand. The gravels are limestone, dolostone and silicified sandstone, rounded in shape and range in size from few centimetres up to $35 \mathrm{~cm}$, but may reach more than $50 \mathrm{~cm}$ and very rarely up to $100 \mathrm{~cm}$. Not well cemented; loose, showing cross bedding structure. The thickness is highly variable along the course and even in nearby areas, it ranges up to $5 \mathrm{~m}$, but as average ranges from $(1-3) \mathrm{m}$.

Glacis (Holocene): Depositional and erosional glacis are developed on the slopes along the course of main valleys. Their constituents are highly variable depending on the type of the exposed rocks. The main constituents are carbonates, sand and clay, partly cemented with thickness ranges from $(1-3) \mathrm{m}$ increasing downslopes.

\subsubsection{Solution and Evaporation Units}

The following units are developed:

Sinkholes: These are well developed in different parts of the studied area in different sizes and depths (Figure 4 and Figure 5). They all are of collapse type

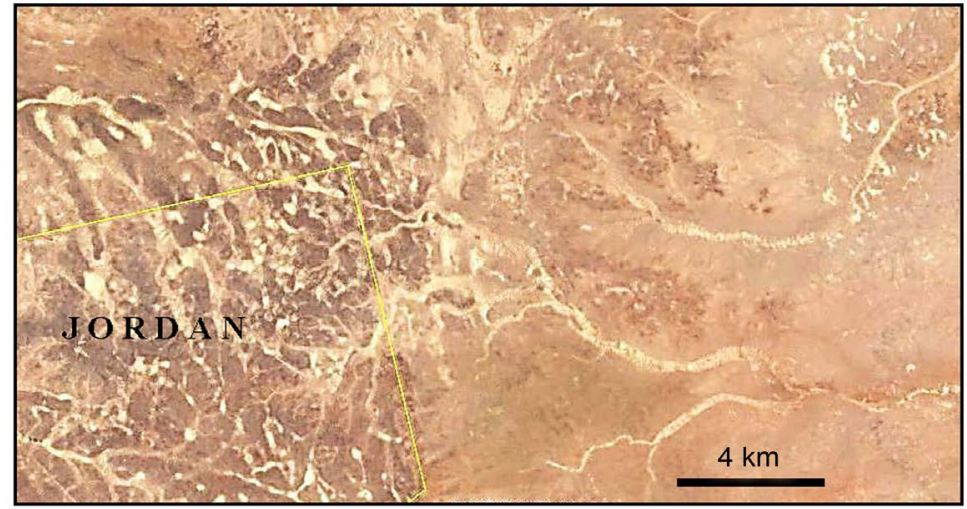

Figure 3. Google earth image showing different shapes of valley fill.

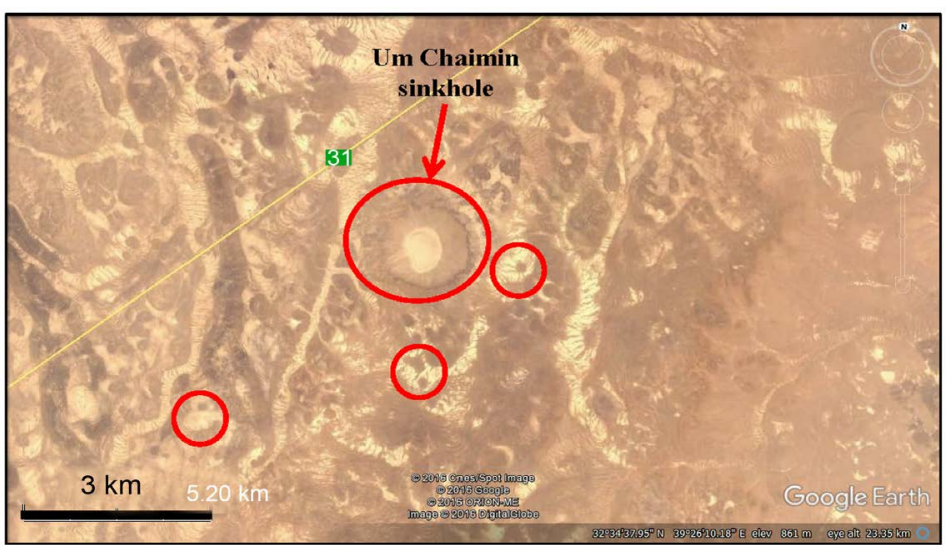

Figure 4. Google earth images showing Um Chaimin sinkholes and others, few are encircled by red color. 


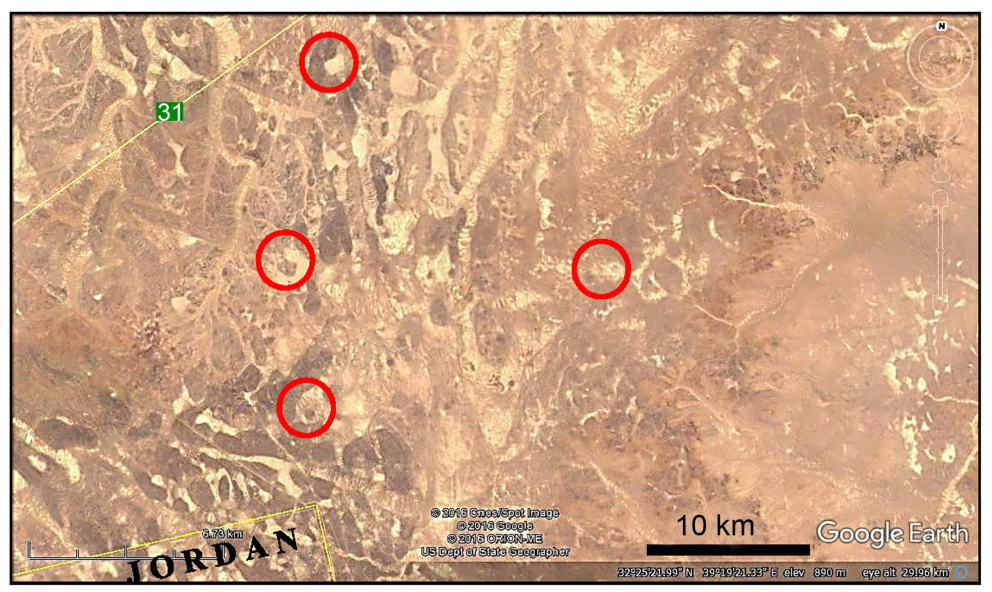

Figure 5. Google earth images showing different shapes of sinkholes, few are encircled by red color.

with circular apertures and either cylindrical or oval shapes. The diameters range from few meters up to $45 \mathrm{~m}$; whereas, the depth ranges from few meters up to $22 \mathrm{~m}$. Apart from Um Chaimin sinkhole, which has $3.3 \mathrm{~km}$ diameter and $63 \mathrm{~m}$ depth [9]. They all are of active type with many chambers in the floor and have significant role on the trend and type of the valleys in the studied area.

Calcrete: Calcrete is developed in different part of the studied area, consists of heterogeneous rock fragments of variable composition cemented by silty, sandy calcareous materials. Locally, they are very hard due to silica cement and exhibit circular rings of reddish brown colour as a sedimentary structure. The thickness ranges from $(1-5) \mathrm{m}$.

\subsubsection{Aeolian Unit}

In different parts of the studied area, accumulation of aeolian sand occurs either in form of sand sheets or Nabkhas. In both cases they are not more than $1 \mathrm{~m}$ in height, usually of very fine sand with pale yellowish brown in color.

\subsubsection{Weathering and Erosion}

Weathering and erosion processes were very active during Pleistocene and even in Holocene, especially during the wet phases of both periods. The development of the main valleys with their main tributaries and other minor valleys with hundreds of their tributaries, beside the intense occurring sinkholes are good indication for the active processes that developed such large valleys and karst forms.

The weathering and erosion resistant of the exposed rocks in different geological formations, which are exposed in the studied area has caused development of different landscapes.

The main erosional types are:

Gulley Erosion: Is the main type of erosion along the courses of main valleys like wadi Hauran, especially in meandering areas. In such areas, under bank and over bank erosion are common; usually associated with rock toppling in the 
former case and channeling in the flood plain sediments in the latter case.

Sheet Erosion: This type of erosion is common in the flat areas, especially in the western parts of the studied area, also on flat areas of wide flood plains.

Rill Erosion: This type of erosion is very rare; only where the soft rocks dominate over the hard rocks; therefore, the main landscape is hummocky with dense cliffs of different sizes; along the slopes of those cliffs the rill erosion is very active.

\subsection{Tectonics and Structural Geology}

The studied area is located in the Western Desert Subzone within the Inner Platform of the Arabian Plate [10]. The subzone is generally characterized by simple tectonic scheme and almost without structural geological features, apart from faults of different types [11]. However, it is characterized by the presence of intense lineaments of different directions that have significant role on the trend and shape of the valleys; not only inside the Iraqi territory, but even in Jordan (Figure 6). Moreover, two normal faults trending almost E-W are present in the study area too (Figure 6).

\subsection{Stratigraphy}

The exposed rocks in the studied area range in age from Cretaceous to Eocene with many types of Quaternary sediments. This range of age includes 7 geological (Figure 7) formations with wide variety of rocks within the formations and locally within the same formation. Consequently, this diversity in the lithology

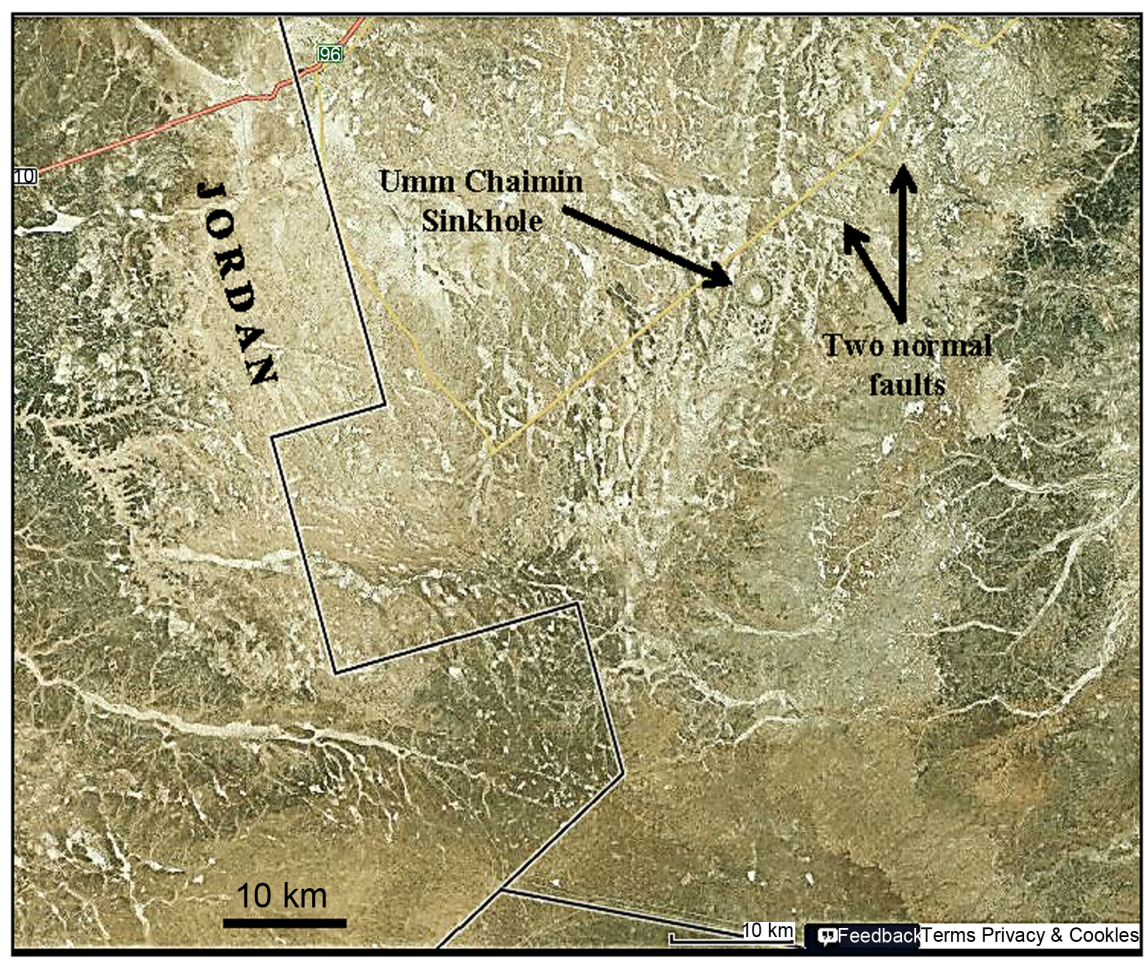

Figure 6. FLASH earth image showing intense lineaments of different directions. 


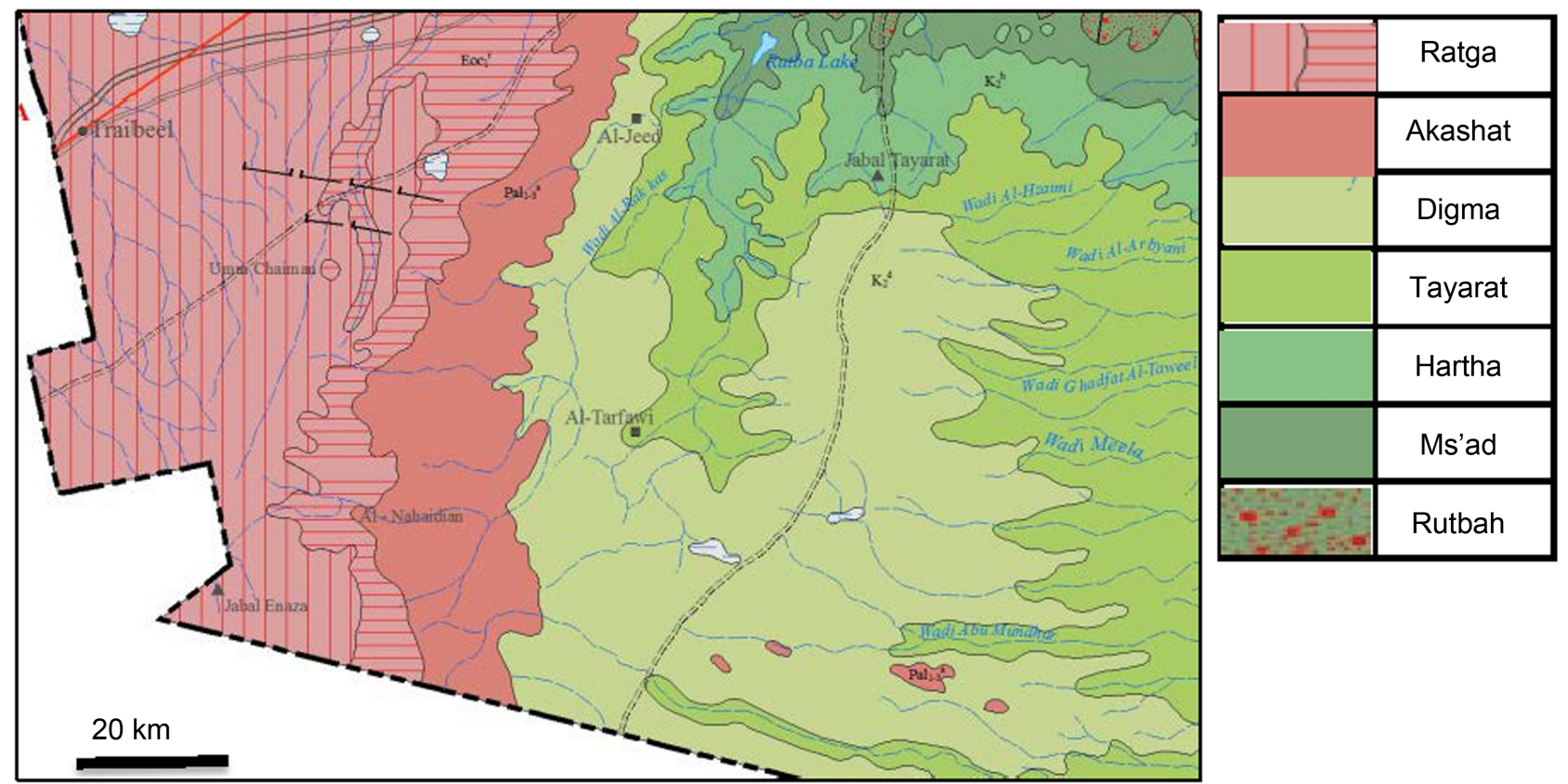

Figure 7. Geological map of the studied area (after [11]).

has formed different forms of valleys in the studied area.

The exposed geological formations are described very briefly depending on [6]; their geographical distribution is shown in Figure 7.

Rutbah Formation (Upper Cretaceous): The formation consists of white and ferruginous sandstone. The thickness ranges between $(23-33) \mathrm{m}$. The formation is overlain unconformably by the M'sad Formation.

M'sad Formation (Upper Cretaceous): The formation consists of varicolored sandy dolostone, and dolostone. The thickness ranges between $(8-65) \mathrm{m}$. The formation is overlain unconformably by the Hartha Formation.

Hartha Formation (Upper Cretaceous): The formation consists of conglomerate and sandstone overlain by marl and dolostone. The thickness ranges between ( 85 - 162) m. It is overlain conformably by the Tayarat Formation and locally interfingers with it.

Tayarat Formation (Upper Cretaceous): The formation consists of rusty sandy siltstone with hematitic concretions. Overlain by marl, siltstone and sandstone with chert nodules, followed by reddish or varicolored detrital limestone with Loftusia. The thickness ranges between $(10-50) \mathrm{m}$. The formation is overlain conformably by the Digma Formation and locally interfingers with it.

Digma Formation (Upper Cretaceous): The formation consists of white to creamy limestone, dolostone with phosphorite horizon and green to ocher papery shale, with oyster shell horizon. The thickness ranges between $(12-40) \mathrm{m}$. The formation is overlain unconformably by the Akashat Formation.

Akashat Formation (Paleocene): The formation consists of alternation of grey phosphorites and limestones. The thickness of the formation ranges between $(30-54) \mathrm{m}$. The formation is overlain conformably by the Ratga Forma- 
tion.

Ratga Formation (Eocene): The formation consists of nummulitic limestone, phosphorite and phosphatic limestone, fine crystalline limestone, with several chert horizons. The thickness of the formation ranges between $(90-100) \mathrm{m}$, it covers the western half part of the studied area and is highly karstified showing intense lineaments of different trends. The formation is overlain unconformably by the Sheikh Alas Formation.

Quaternary Sediments: Different types of Quaternary sediments occur along the course of wadi Hauran of Pleistocene and Holocene ages. Their types and composition are given within the description of Geomorphological units.

\section{Drainage Patterns}

Different types of drainage patterns are developed in the studied area, which are the main concept of this study. The most common types are:

Dendritic Drainage Pattern: This type of drainage is developed in the upper reaches of almost all valleys (Figure 6), but not along the main course of the valley, also along the cliffs where the majority of the rocks are not hard.

Annular Drainage Pattern: This type of drainage pattern is developed in restricted areas where the landscape is intensely karstified (Figure 8).

Parallel Drainage Pattern: This type of drainage is rarely developed along the slopes of some cliffs that are under the influence of rill erosion, especially where soft rocks are exposed along the slopes. Besides those, which run following the regional gradient of the area, especially where the Lower Cretaceous rocks are exposed (Figure 7 and Figure 8) and those which are controlled by lineaments (Figure 8).

\section{Valley Forms and Directions}

The valleys in the studied area have different forms and trends; this is attributed
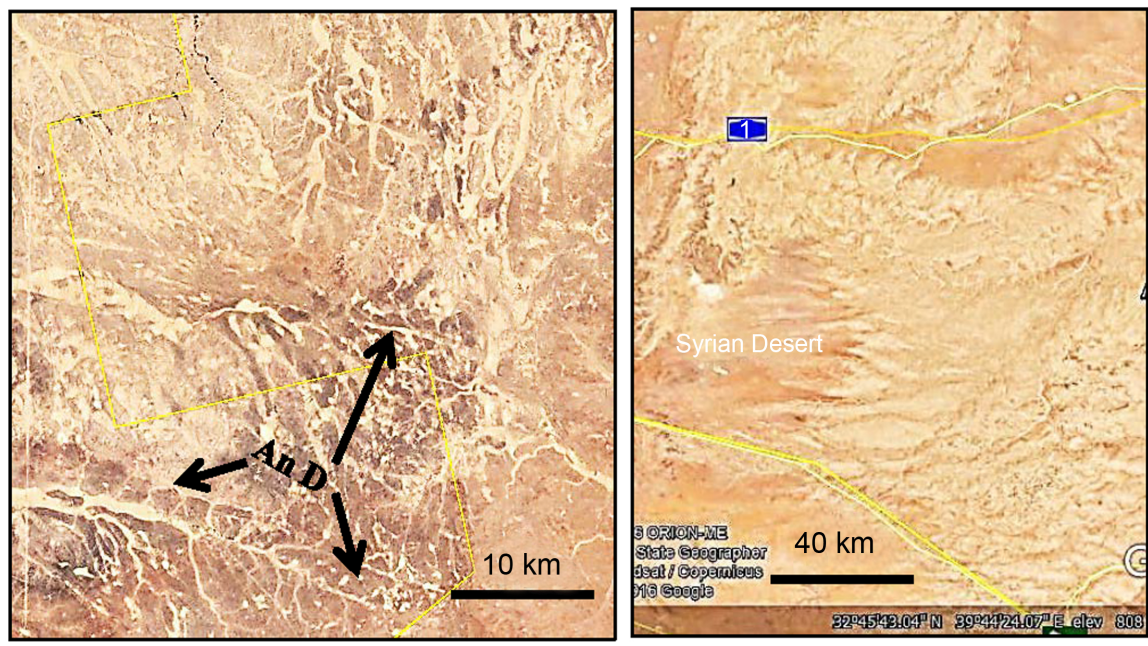

Figure 8. Google earth image showing. Left: Annular drainage pattern (An D), Right: Parallel drainage patterns. 
to the intense karstification and the role of the tectonics as presented in the presence of intense lineaments of different directions, beside the lithology of the exposed formation and their thicknesses.

\subsection{Valley Forms}

The following valley forms are developed in the studied area:

Wide and Shallow Valley Form: The courses of the valleys are wide and shallow with very gentle and wide banks.

Wide and Deep Valley Form: The courses of the valleys are wide and shallow with gentle and deep banks.

Narrow and Deep Valley Form: The courses of the valleys are narrow and shallow with very steep and narrow banks; canyon like, especially in Hauran valley and those, which run in the cretaceous rocks (Figure 7) in the eastern part of the studied area.

\subsection{Valley Trends}

In the extreme southwestern part of the studied area (Figure 9), the valleys have different trends starting almost from certain area in which it is almost impossible to identify where the trend of a particular valley is. Moreover, each valley of certain trend has different shape from the others. They are either controlled by lineaments and/or karistification.

In Figure 10, there are two main normal faults (A-B and C-D) [1] [11]. The two faults, which are located north of Um Chaimin sinkhole (Figure 11) have controlled the valleys; beside they shifted their trends and changed the shapes and widths.

Different types of valleys can be seen in Figure 10, like parallel, annular and

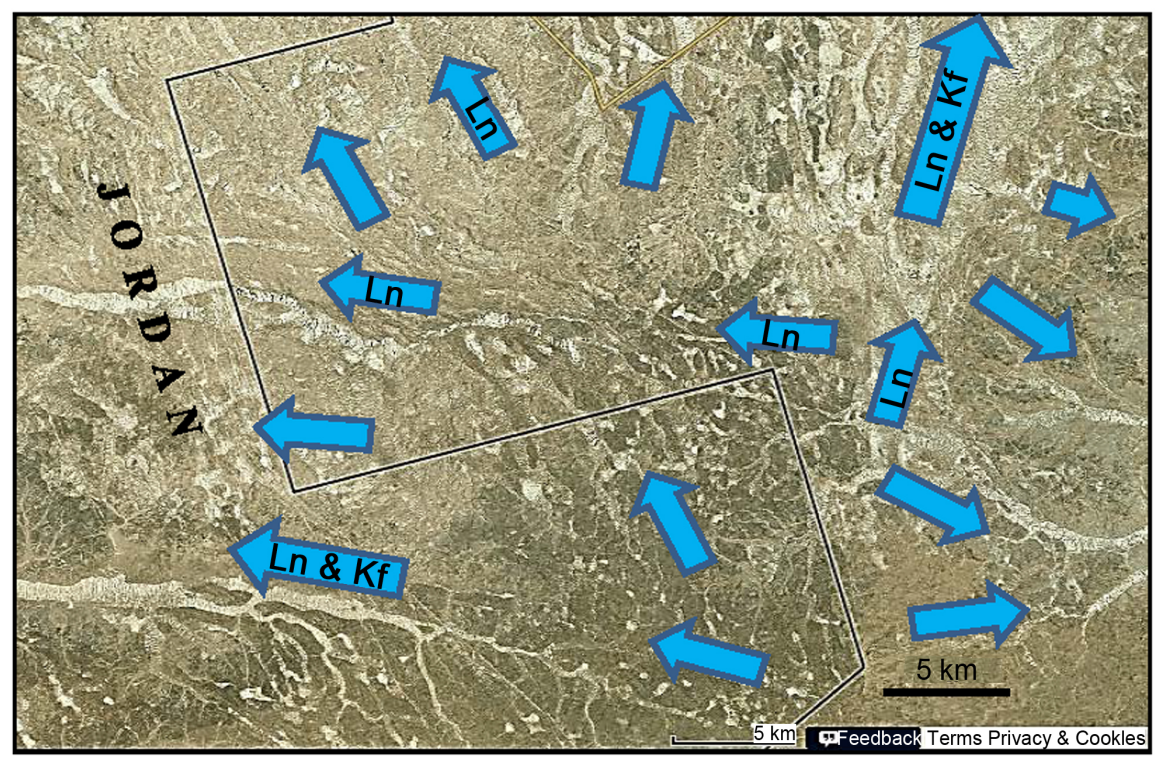

Figure 9. HERE map image showing different trends of valleys and different forms, either controlled by lineaments (Ln) or Karst forms (Kf). 


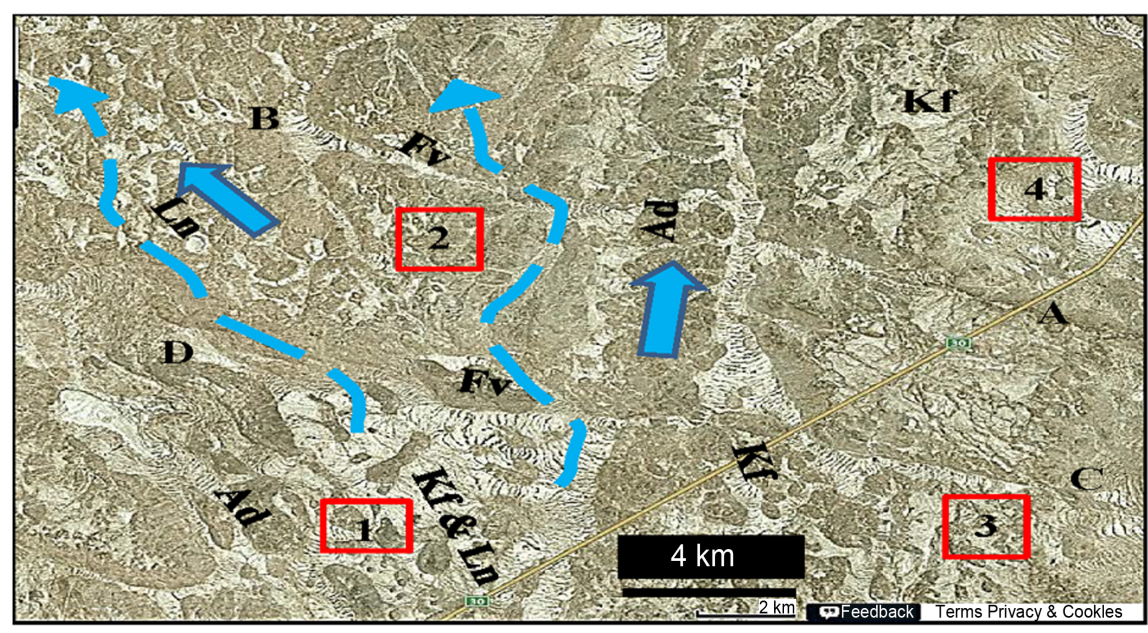

Figure 10. HERE map image showing valleys controlled by fault (Fv), lineaments (Ln) and karst forms (Kf). Also note the annular drainage pattern (Ad).

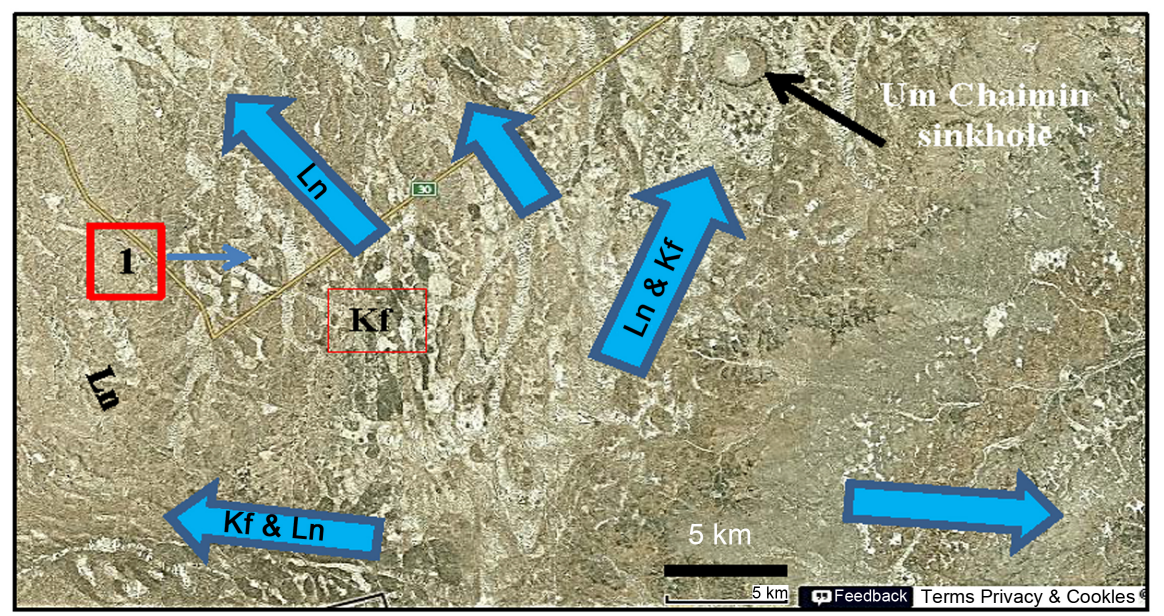

Figure 11. HERE map image showing Um Chaimin sinkhole and valleys controlled by lineaments (Ln) or by karst forms (Kf).

circular. Moreover, valleys have changed their trends into different directions; being controlled tectonically.

Locally, the direction of the valleys is not recognizable due to intense karstification and the presence of intense lineaments, like in points 1, 2, 3 and 4 (Figure 10). The intense karstification and the lineaments have changed the directions of the valleys within very small areas. Consequently, hindering the valleys' trends, and have caused the development of abnormal shapes, widths and trends of the valleys.

In Um Chaimin sinkhole vicinity (Figure 11), the valleys also have different trends, and locally it is hardly visible where the trends of the valleys are. Moreover, they are also either controlled by lineaments and/or Karst forms. Those of straight directions are controlled by lineaments, whereas those of circular shapes are controlled by karst forms.

To the east of the Point 1 in Figure 11, circular valleys can be seen in concen- 
tric forms. Beside the central part, two concentric valleys are developed, although they are not completely circular. Moreover, the outer circular form has three loops; indicating three continuous circular forms, which have conjugated together; consequently, indicating that the valleys are controlled by karst forms.

In the eastern part of the studied area where the Upper Crteaceous rocks are exposed (Figure 7), all the valleys flow eastwards (Figure 1) following the topography. However, some valleys are truncated in their middle parts (Figure 12). For example, at point $\mathrm{A}$ the valley is truncated and is continuous eastwards. As well the valley between B and C is truncated and the western part is directed northeast wards to the point $\mathrm{D}$, there the small branch is truncated too. In all cases the traces of the old valleys are clear.

In the extreme western part of the studied area, near the Iraqi-Jordanian International borders (Figure 13); especial drainage pattern is developed due to karst forms giving the landscape wavy form. The enlarged image shows details of the wavy landscape due to the karst forms, which has changed the direction of the valleys around the karst forms (Figure 14); indicating that the karstification is still active.

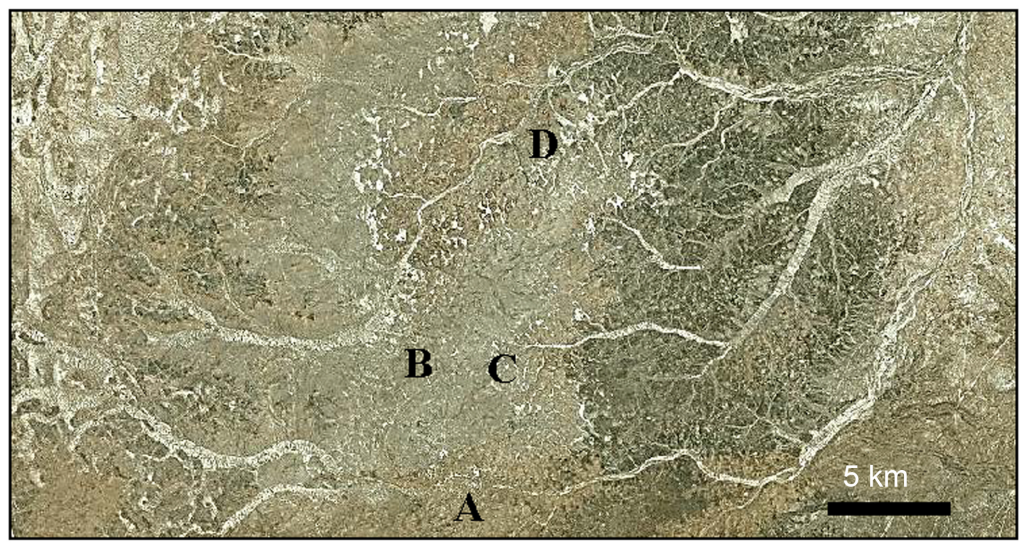

Figure 12. HERE map image showing truncated valleys and changing their trends due to neotectonic activity.

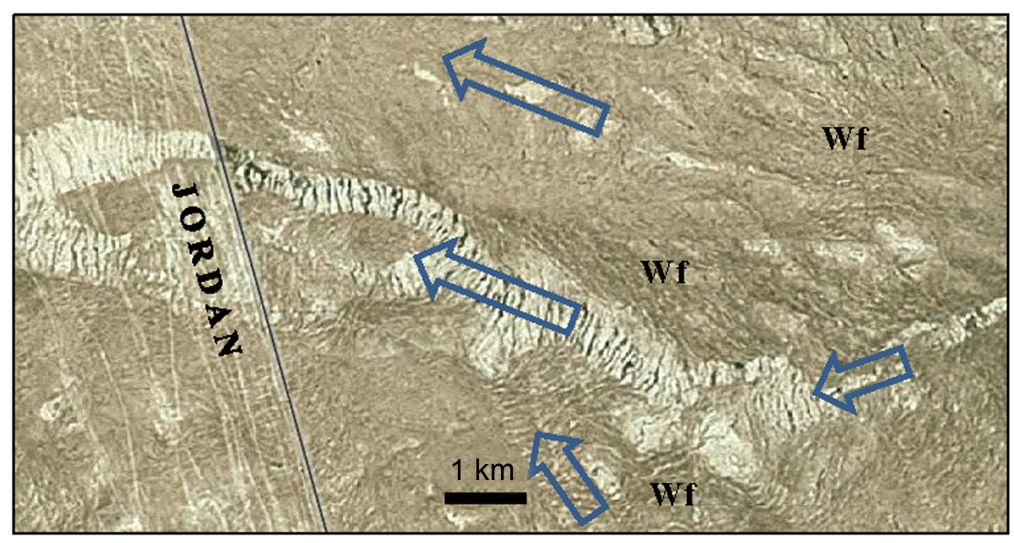

Figure 13. HERE map image showing the influence of karst forms on the trend of the valleys giving them wavy form (Wf). 
In the extreme southeastern part of the studied area, near the Iraqi-JordanianSaudi Arabian International triple point (Figure 15), a special and very rare landform is developed due to intense karstification of the area. The trends of the valleys are obscure due to very intense karstification, which has developed a special landscape of worms shape (Figure 15).

In the western part of the studied area, along the Iraqi-Jordanian International borders, annular drainage pattern is developed (Figure 16). This pattern is developed due to both karstification and the presence of lineaments; both factors have dissected the valleys in polygonal shapes. In the Jordanian part, the annular pattern is clearer.

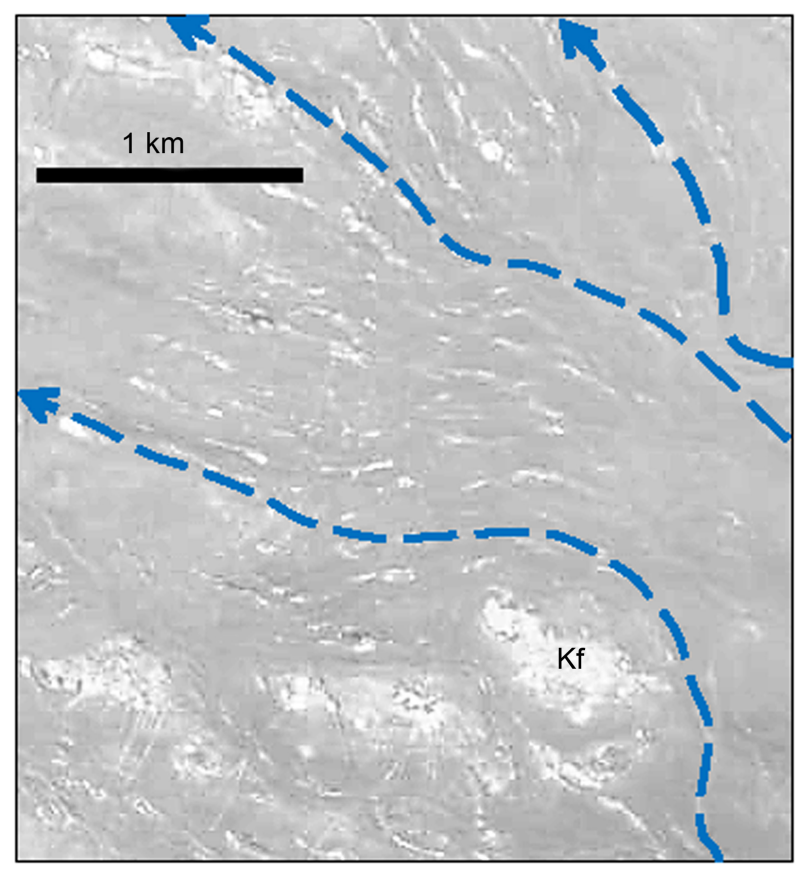

Figure 14. Enlarged HERE map image showing the influence of the karst forms (Kf) on the trend of the valleys.

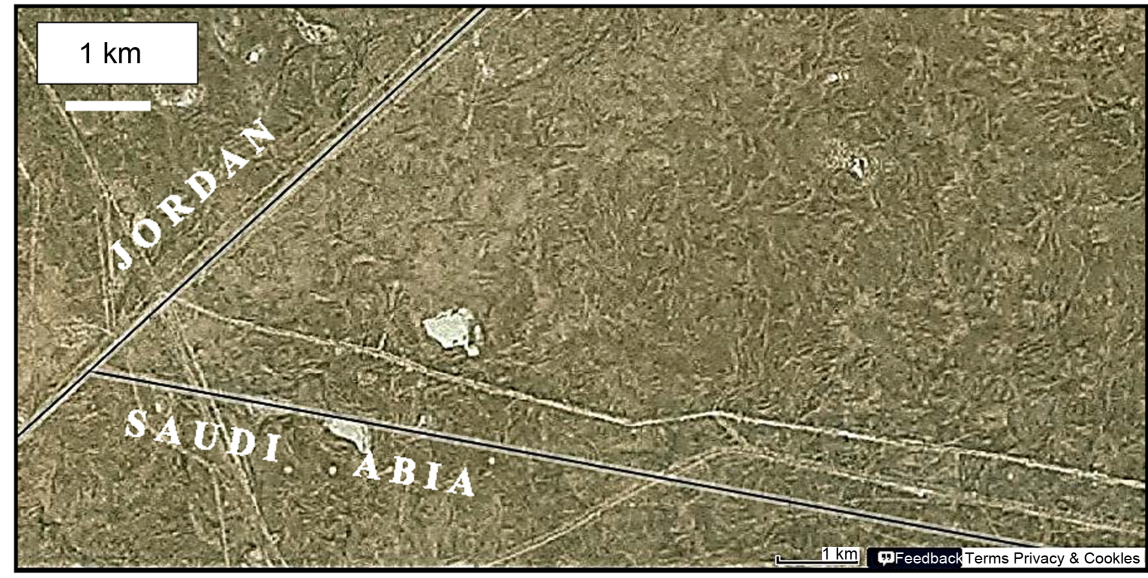

Figure 15. HERE map image showing very intense karstification, which has developed very special and rare landform, resembling worms shape. 


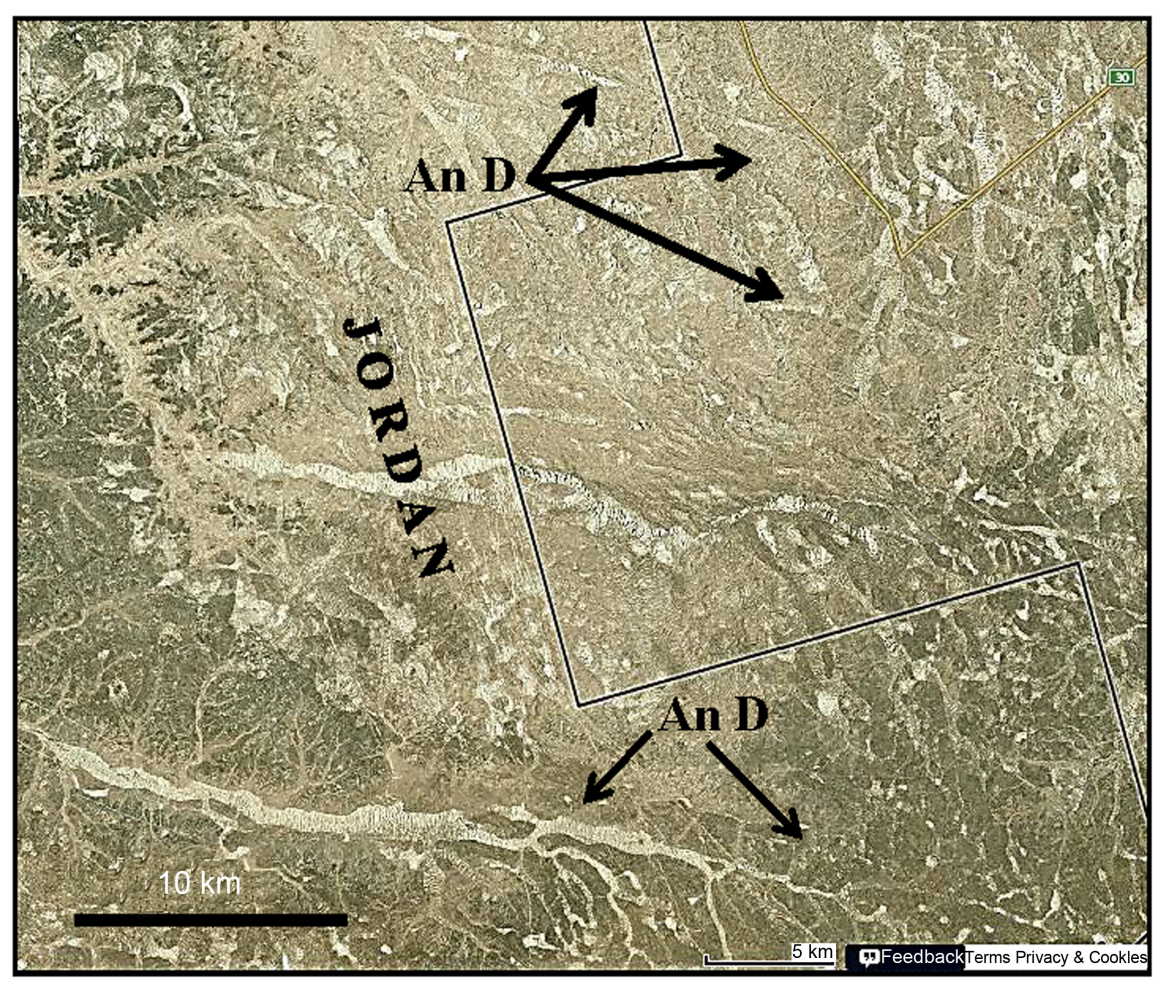

Figure 16. HERE map image showing annular drainage pattern (An D).

\section{Discussion}

Although the western part of the studied area is covered by rocks of the Ratga Formation (Figure 7); consists mainly of carbonates in homogeneous form and regional eastward gradient, still abnormal drainage patterns, shapes and trends of valleys are developed. From the aforementioned examples of the diversity of the drainage system; their types, shapes and directions, it is very obvious that there are abnormal shapes, trends and behaviours of the valleys in the studied area, even within a small area (Figure 9). All the mentioned examples are controlled either by karstification or structurally (either controlled by intense lineaments or faults); however, locally both factors have contributed (Figures 9-11).

To check whether the trends of the valleys are related to subsurface factors too, many aspects were studied, among them are:

\subsection{DEM Image}

It is very clear from the DEM image (Figure 17) that not only the studied area, but even regionally the area is intensely dissected by lineaments of different directions. Locally, the intersection of lineaments and the presence of karst forms have developed annular drainage pattern (Figure 16). Moreover, it is clearly obvious that the valleys have different trends and the tectonic (expressed by lineaments) and karstification have controlled the trends and the shapes of the valleys, as well. 


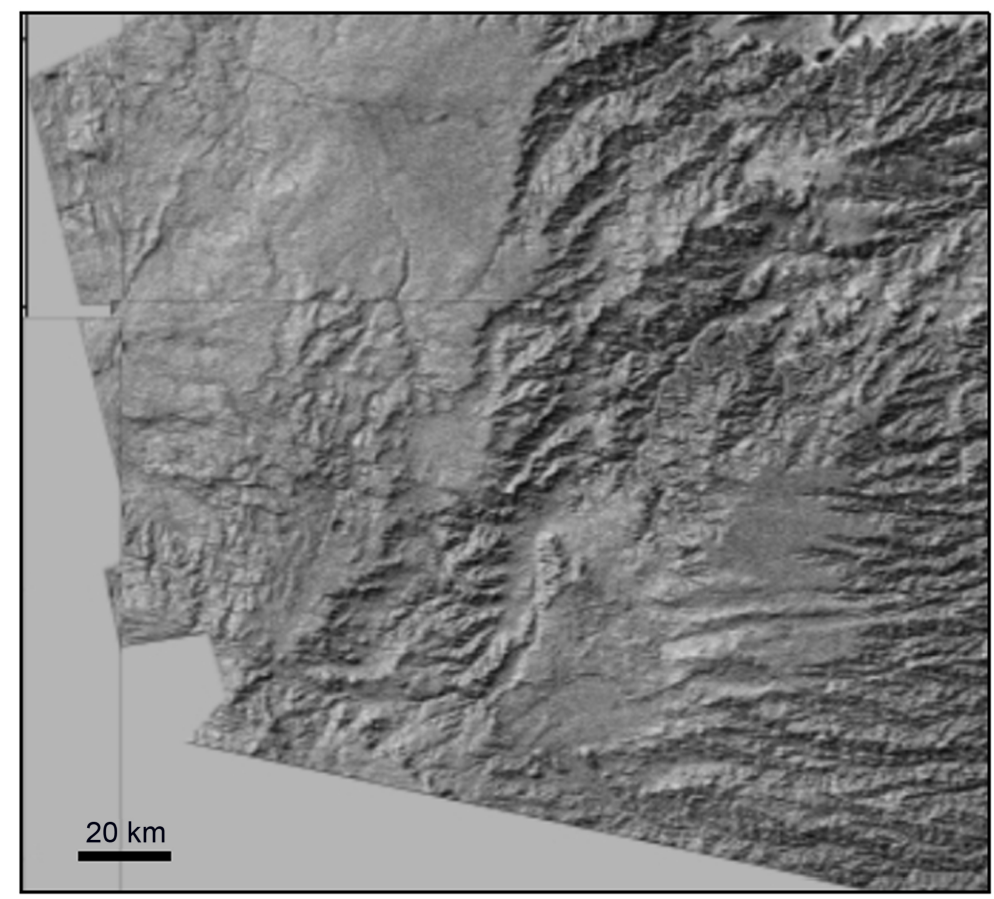

Figure 17. DEM image of the studied area showing intense lineaments.

\subsection{Hydrogeological Map}

The compiled hydrogeological map [7] of the studied area and near surroundings (Figure 18) shows that the ground water moves in different directions. It is obvious that the surface water flow directions (Figures 9-11), have no any relation with the groundwater flow direction, apart from the eastern part where both surface and ground water flow eastward following the regional gradient. Although it is not necessary to coincide surface and subsurface water flow directions; however, in this particular area, it may be attributed to the used data for compilation of the hydrogeological map was not adequate, since the distance between the used water wells range from $(20$ - 100) Km. Moreover, the domal form that causes the ground water to flow in opposite directions (Figure 18) coincides with the location of Hauran valley, which is the largest valley not only in the studied area, but in Iraq and it forms large basin for the valley. Its width ranges up to $35 \mathrm{~km}$ [8]. It is worth to mention that the groundwater flow direction [7] is not influenced by the dense regional lineaments (Figure 17).

\subsection{Structural Map}

The complied structural map [12] of the studied area (Figure 19) shows many surface and subsurface structural features. However, majority of them did not coincide with the trends of the valleys, which means they have not influenced on the trends. A good example is the two normal faults (Figure 1 and Figure 10) north of Um Chaimin Sinkhole; they dissected many valleys and changed their trends (Figure 10), but they did not exist in the structural map (Figure 19).

The absence of the influence of the structural features shown in the structural 


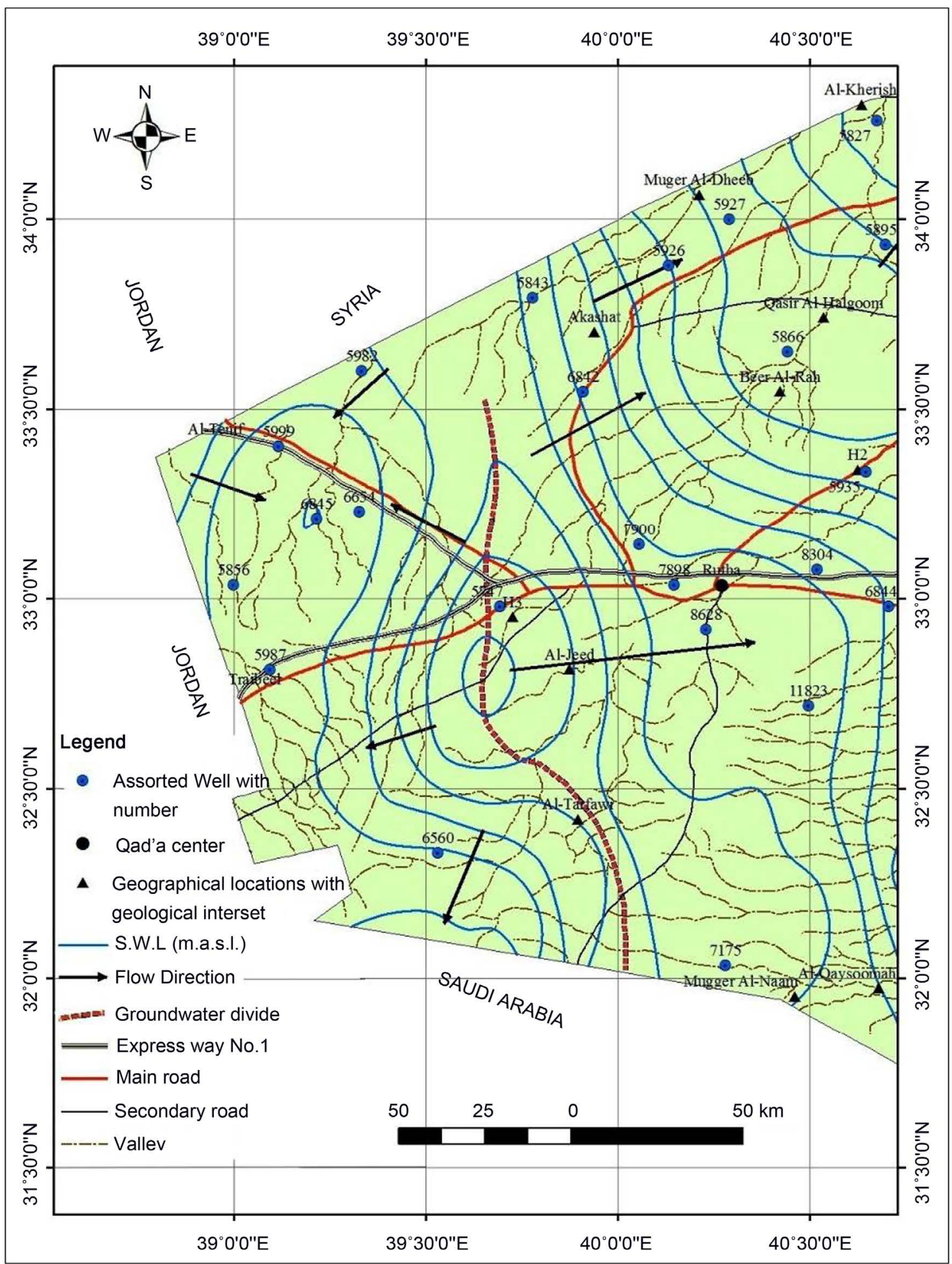

Figure 18. Hydrogeological map of the studied area and near surroundings (after [7]).

map (Figure 19) can be attributed to: 1) The subsurface features are deep enough; therefore, there is no influence of the surface, or they didn't show surface manifestation, 2) the used gravity and magnetic data are inadequate to deduce the correct positions, extensions and trends of the interpreted subsurface 


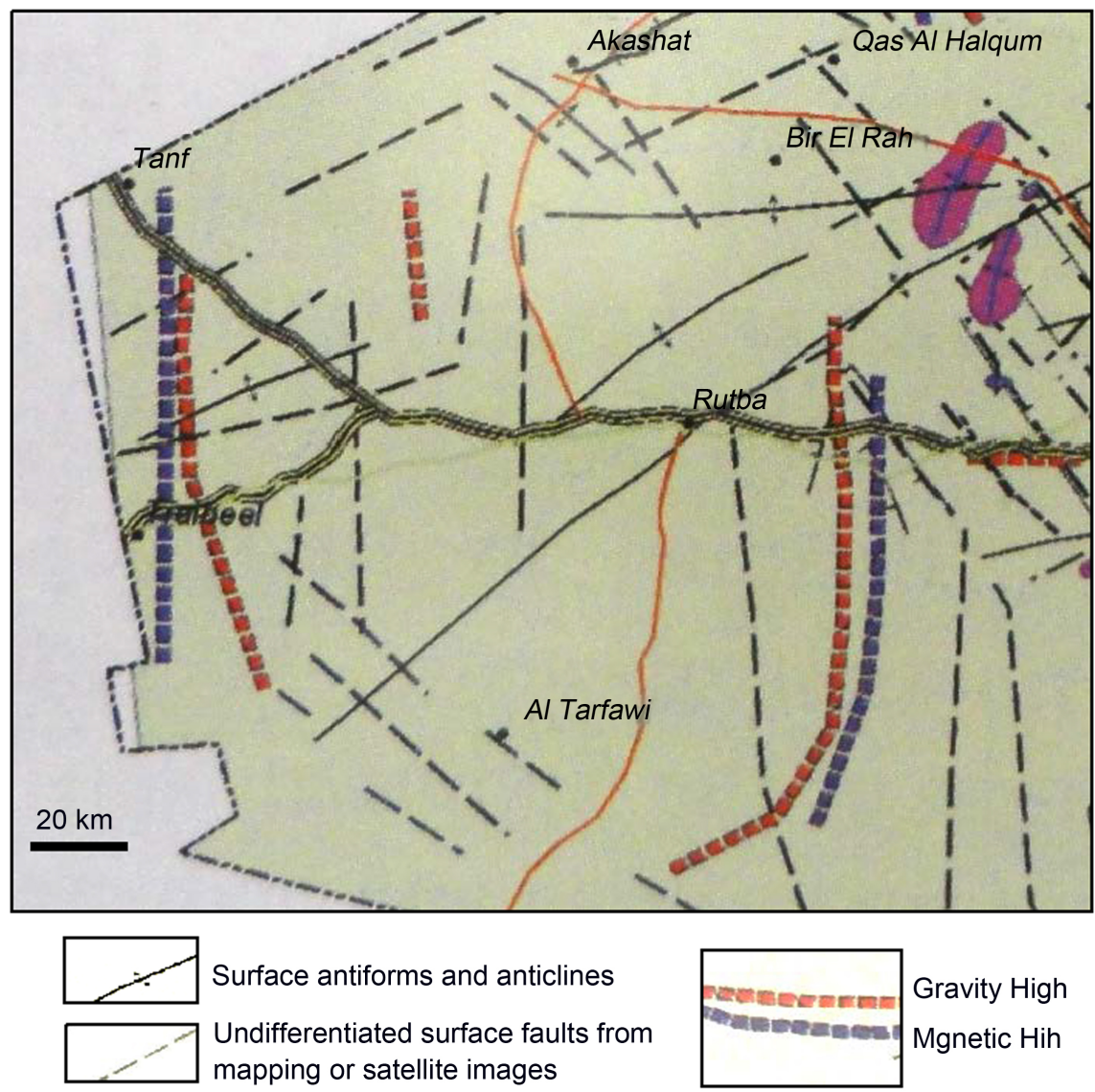

Figure 19. Structural map of the studied area and near surroundings (after [12]).

data, 3) the interpreted surface features are mainly lineaments; as can be seen in the DEM image (Figure 15) and not all of them are presented on the map due to scale limitation.

It is worth mentioning that [10] compiled the Tectonic Map of Iraq, but no surface and/or subsurface data is presented in the studied area.

\subsection{Geophysical Maps}

Two compiled geophysical maps [12] were used to deduce the subsurface influence on the trends of the drainage system in the studied area, the Residual Gravity Map and Total Magnetic Map (Figure 20).

In the Total Residual map (Figure 19(a)), the grey polygons represent gravity residuals. Some of them coincide either totally or partly with the surface karst features and the main trend of the large valleys. The dashed red lines represent faults; some of them coincide with the existing lineaments.

In the Total Magnetic Map (Figure 19(b)), some of the magnetic anomalies, especially in the extreme western part of the studied area coincide partly with the main trends of large valleys. However, in the extreme southwestern part of the studied area, where the trends of valleys are in four different directions (Figure 10 ), no any indication can be seen on the Total Magnetic map. 

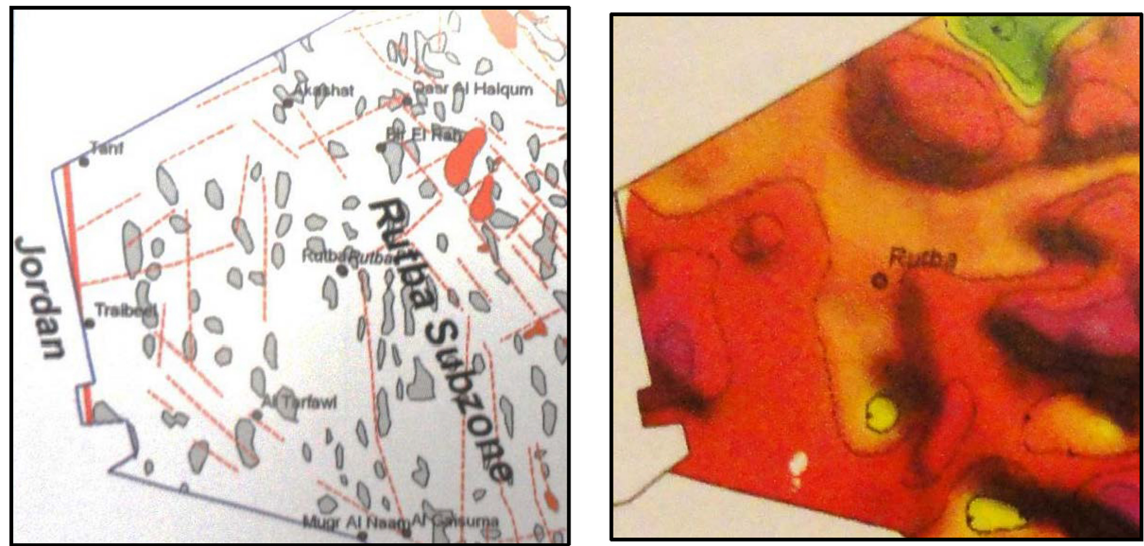

Figure 20. Left: Residual gravity map. Right: Total magnetic field map (after [12]).

The non-coincidence of the trends of the valleys with the presented data in the two used geophysical maps can be attributed to: 1) The subsurface features are deep enough; therefore, there is no influence of the surface, or they didn't show surface manifestation, 2) The used gravity and magnetic data are inadequate to deduce the correct positions, extensions and trends of the interpreted subsurface data, 3) The interpreted surface features in the Residual Gravity map are mainly lineaments; as can be seen in the DEM image (Figure 16) and not all of them are faults as presented in concerned map.

\subsection{Neotectonic Map}

The Neotectonic map of Iraq [13] sows no any data in the studied area about the presence of neotectonic activity (Figure 21). Apart from the last drawn contour line that represents upwards of $400 \mathrm{~m}$ (Figure 21) during the Upper Miocene, no other indication exists on the map. This contradicts with the truncated two valleys in the southern part of the studied area (Figure 12), which is attributed by the current author to neotectonic activity. This is attributed to: 1) The Neotectonic map is a regional map, 2) Local indications for neotectonic activities cannot be presented on the map due to scale limitations, 3) The concept of the compiled Neotectonic Map of Iraq doesn't include such local data, since it includes the uplift and/or down warp of the beds starting from the Upper Miocene, which represents the starting of Neotectonic Movements in Iraq, and 4) This local uplift in the concerned area (Figure 12) is most probably very recent, since the old courses of the truncated valleys are still visible.

It is worth mentioning the neotectonic activity is not restricted to the above mentioned area (Figure 22). A good example is the recently developed drainage system (Figure 22) just west of the Iraqi-Jordanian International borders. The recently developed drainage system crosses the already existing drainage system indicating neotectonic activity. Another example is shown in Figure 23, where the already existing drainage system is crossed by recent drainage, which is controlled by NE-SW lineaments causing shifting of the already existing drainage system. The estimated shift in the drainage is about $(2-3) \mathrm{Km}$. These neotectonic 


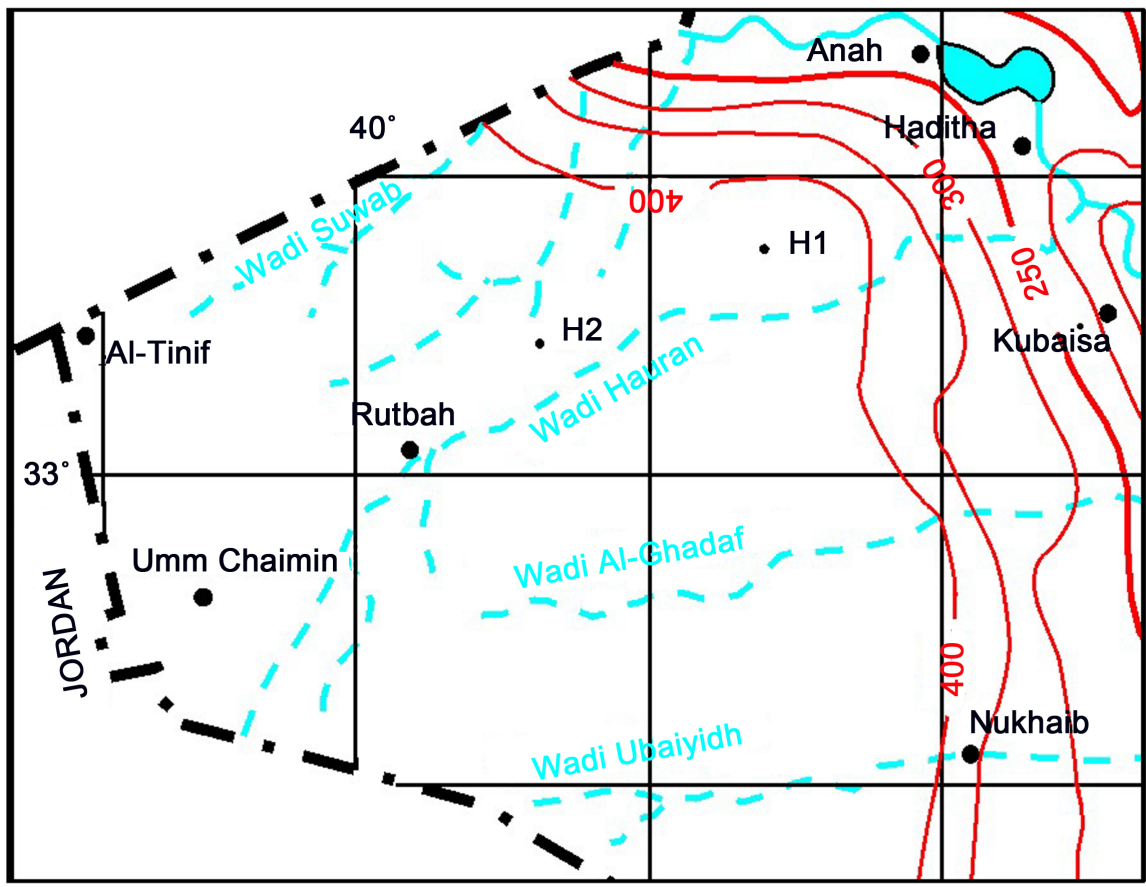

Figure 21. Neotectonic map of the studied area and near surroundings (after [13]).

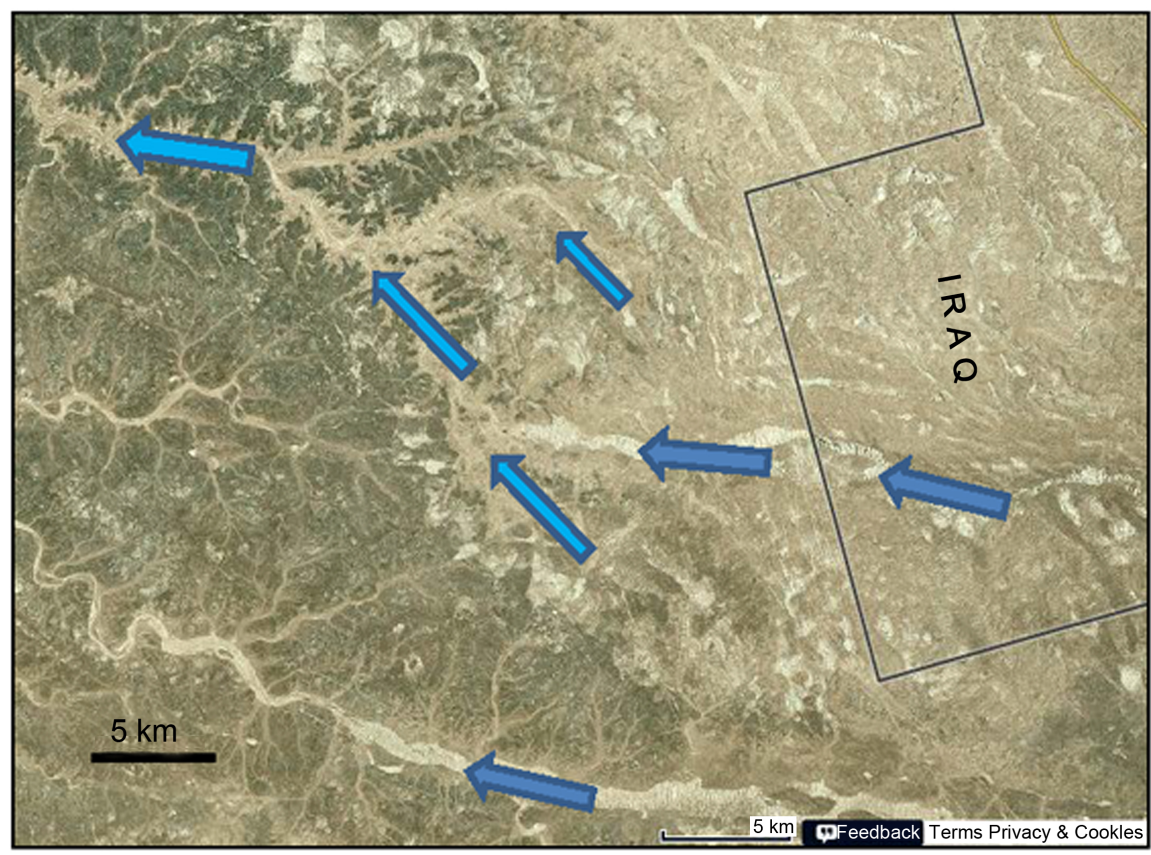

Figure 22. HERE map image showing recently developed drainage system $(\longrightarrow)$ crossing the existing drainage system indicating neotectonic activity.

movements may be are related to the activity of Hail-Rutba Arch, or any other local activity that has caused the mentioned drainage shifts.

In contrary to the western part of the studied area and all the present abnormal drainage systems, their shapes and trends, the eastern part shows very normal drainage system following the regional topographic gradient towards the 


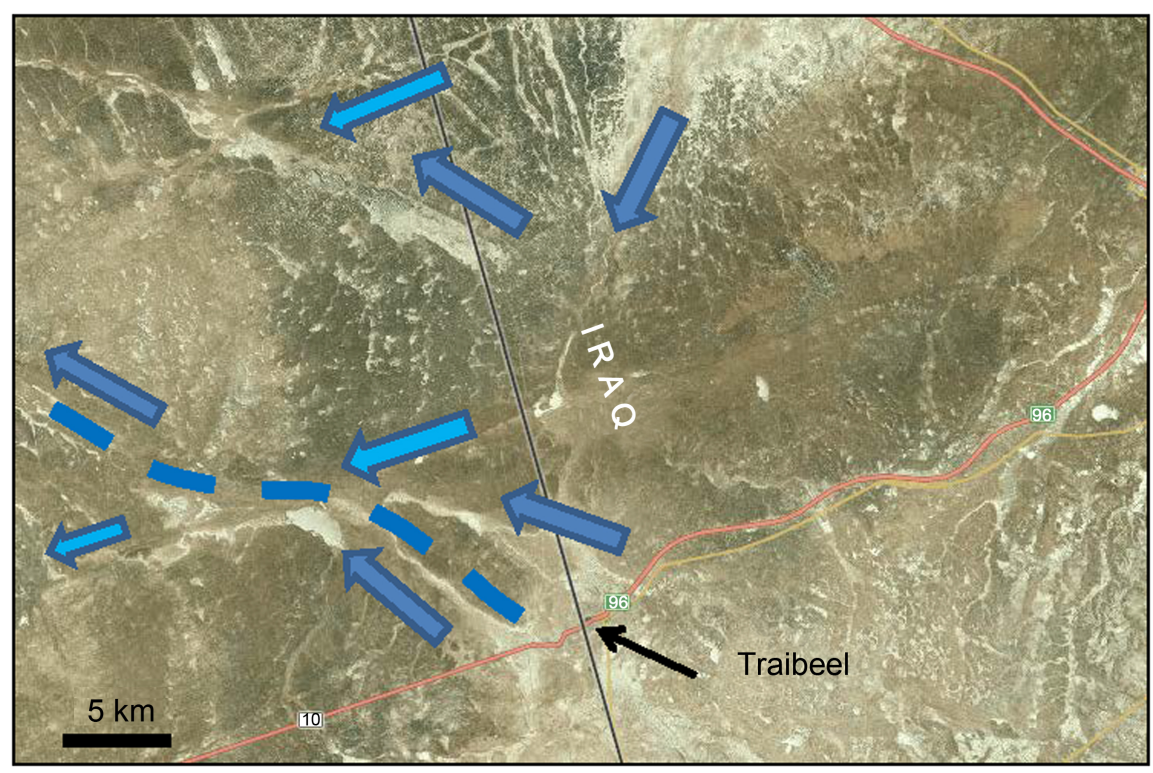

Figure 23. HERE Earth image showing crossing of two drainage systems of different ages; indicating neotectonic activity.

east. This is attributed to: 1) Absence of karstification; although carbonate rocks form the major constituent of the exposed formations, but all of them are intercalated by marl, claystone and fine clastics, and rarely conglomerate, 2) Absence of the lineaments, which indicate tectonic rest of the area; not like the western part of the studied area, and 3) Absence of neotectonic activity in the area. However, there is one main water divide line between those valleys that drain east wards and wadi Hauran that trends northwards (Figure 1), the water divide may represent part of Hail-Rutbah Arch.

\section{Conclusions}

The western part of the studied area is characterized by intense karstification and the presence of lineaments of different trends and extensions, beside indications for Neotectonic activity. All those features have contributed in development of abnormal drainage patterns with different trends, shapes and sizes. Locally, those features have contributed in development of certain drainage pattern; like annular pattern.

Locally, and especially in the extreme southwestern corner of the studied area, the trends of the valleys are in (4 - 6) different trends, usually controlled by lineaments and/or karst forms. However, locally both lineaments and karst forms control their trends and shapes.

Clear indication for neotectonic activity occurs in the upper reaches of wadi Hauran, as two branches are truncated and shifted from their original trends. The old courses are still present. Another indication for neotectonic activity is the offset of many valleys along major valleys that are controlled by very long lineaments.

The present karst forms and lineaments are surface features. When comparing 
the available geophysical and hydrogeological data, almost no coincidence can be seen between the surface and subsurface features. However, very rarely some lineaments coincide with some geophysical anomalies.

Two regional E-W trending normal faults have dissected the valleys in the northern part of the studied area and have shifted their trends; partially but effected on their widths extremely.

\section{References}

[1] Hagopian, D.H. (1979) Regional Geological Mapping of Nhaidain-Tinif Area. Iraq Geological Survey (GEOSURV) Library Report No. 983.

[2] Buday, T. and Hak, J. (1980) Report on Geological Survey of the Western Part of the Western Desert, Iraq. Iraq Geological Survey (GEOSURV) Library Report No. 1000.

[3] Al-Bassam, K.S., Karim, S.A., Hassan, K.M., Saeed, L., Yakta, S. and Salman, M. (1990) Report on Geological Survey of the Upper Cretaceous-Lower Tertiary Phosphorite Bearing Sequence, Western Desert, Iraq. Iraq Geological Survey (GEOSURV) Library Report No. 2008.

[4] Hamza, N.M. (2007) Geomorphology. Geology of the Western Desert of Iraq. Iraqi Bulleting of Geology and Mining, Special Issue No. 1, 9-27.

[5] Fouad, S.F. (2007) Tectonic and Structural Evolution. Geology of the Western Desert of Iraq. Iraqi Bulletin of Geology and Mining, Special Issue No. 1, 29-50.

[6] Sissakian, V.K. and Mohamed, B.S. (2007) Stratigraphy. Geology of the Western Desert of Iraq. Iraqi Bulleting of Geology and Mining, Special Issue No. 1, 51-124.

[7] Al-Jiburi, H.K. and Al-Basrawi, N.H. (2014) Hydrogeology of the Western Desert of Iraq. Iraqi Bulleting of Geology and Mining, 10, 1-20.

[8] Sissakian, V.K., Abdul Ahad, A.D., Al-Ansari, N. and Knutson, S. (2017) The Geology of Wadi Hauran, the Largest Valley in Iraq, Iraqi Western Desert. Asian Earth Science Journal. (In Press)

[9] Sissakian, V.K. and Abdul-Jabbar, M.F. (2008) Using Remote Sensing and GIS Techniques in Detecting the Origin of Umm Chaimin Depression, Iraqi Western Desert. Iraqi Bulletin of Geology and Mining, 4, 51-72.

[10] Fouad, S.F. (2014) Tectonic Map of Iraq, Scale 1: 1000000. 3rd Edition, Iraq Geological Survey (GEOSURV) Publications, Baghdad.

[11] Sissakian, V.K. and Foaud, S.F. (2012) Geological Map of Iraq. 4th Edition, Scale 1:1000000. Iraq Geological Survey (GEOSURV) Publications, Baghdad.

[12] Jassim, S.Z. and Goof, C.J. (2006) Geology of Iraq. Dolin, Prague and Moravian Museum, Brno, Czech Republic.

[13] Sissakian, V.K. and Deikran, D.B. (2009) Neotectonic Movements in West Iraq. Iraqi Bulletin of Geology and Mining, 5, 59-74. 
Submit or recommend next manuscript to SCIRP and we will provide best service for you:

Accepting pre-submission inquiries through Email, Facebook, LinkedIn, Twitter, etc. A wide selection of journals (inclusive of 9 subjects, more than 200 journals)

Providing 24-hour high-quality service

User-friendly online submission system

Fair and swift peer-review system

Efficient typesetting and proofreading procedure

Display of the result of downloads and visits, as well as the number of cited articles Maximum dissemination of your research work

Submit your manuscript at: http://papersubmission.scirp.org/

Or contact eng@scirp.org 